Dept. of Clinical Studies,

Fac. of Vet. Science, University of Nyala, Sudan.

\title{
SERUM TRIIODOTHYRONINE, THYROXINE, AND THYROID STIMULATING HORMONE CONCENTRATIONS IN DONKEYS FOLLOWING ADMINISTRATION OF DORAMECTIN (EXPERIMENTAL STUDY)
}

(With 3 Tables)

By

\section{H.I. SERI; HUSNA M. EL BASHIR *; Y.H.A. ELMANSOURY ${ }^{*}$ and AMNA E. BABIKER*}

* Dept. of Radioisotopes, Central Vet. Research Laboratory, Soba, Sudan. (Received at 1/9/2007)

تركيز الثايرونين ثلاثي اليود، الثايروكسين والهرمون المنشط للارقية

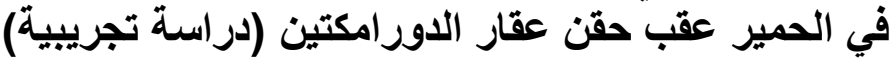

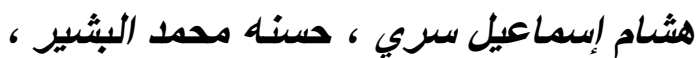

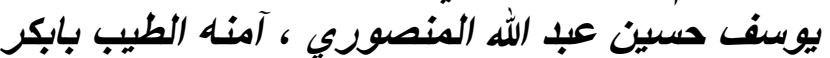

تم إجر اء در اسة لتقويم التسمم دون الحاد للادورامكتين المحقون في الحيو انات السليمة إكلينيكيا.

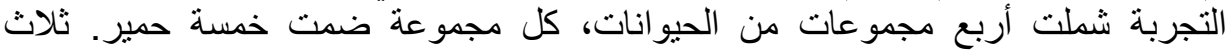

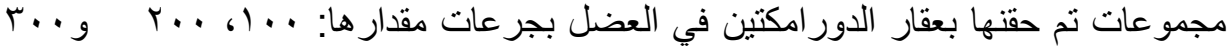

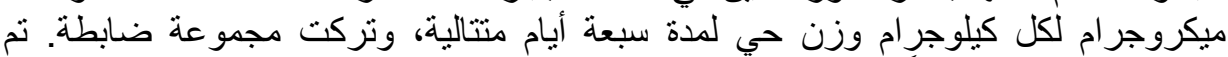

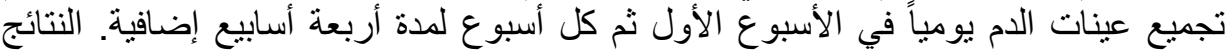

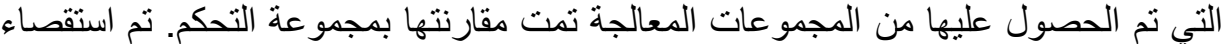





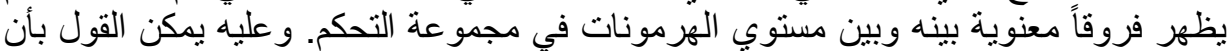

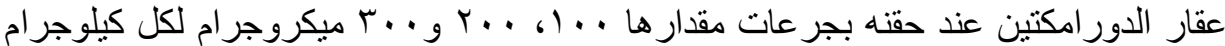

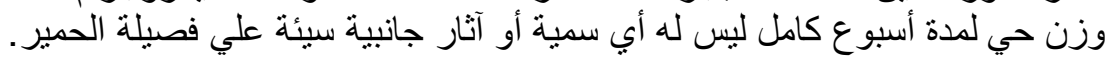

\section{SUMMARY}

The objectives of this experiment were to determine serum concentrations of Triiodothyronine $\left(\mathrm{T}_{3}\right)$, Thyroxine $\left(\mathrm{T}_{4}\right)$, and Thyroid Stimulating Hormone (TSH) following administration of the anthelmintic Doramectin in healthy donkeys. This was done to 
investigate the sub acute effect of doramectin injectable formulation in donkeys. Serum $\mathrm{T}_{3}, \mathrm{~T}_{4}$ and $\mathrm{TSH}$ concentrations in serum samples obtained before and after doramectin administration for continuous 7 days, were determined using RIA technique. Baseline values ranged from 0.32 to $1.63 \mathrm{ng}$ of $\mathrm{T}_{3} / \mathrm{ml}, 3.13$ to $22.61 \mathrm{ng}$ of $\mathrm{T}_{4} / \mathrm{ml}$, and $0.34-1.01 \mathrm{mIU} / \mathrm{L}$ of TSH. There are no significant $(\mathrm{P}>0.05)$ differences between the treatment groups and the control for the concentration of the three hormones under investigation, but there is significant increase in the level of hormones when compared with the pre treatment level in all groups.

Key words: Doramectin, donkeys, Triiodothyronine, Thyroxine, Thyroid Stimulating hormone.

\section{INTRODUCTION}

Doramectin (DRM) is an avermectin compound obtained by mutational biosynthesis, by feeding cyclohexane carboxylic acid to a genetically - engineered strain of $S$. avermitilis and, as a result, has a cyclohexyl group at the $C_{25}$ position (Goudie et al., 1993). Doramectin and Ivermectin are endoectocide compounds with exceptional potency. They have broad nematode and arthropod spectra.

Normal thyroid hormone concentrations reported for horses have a wide range of values (Kallfelz and Erali, 1973; Reap et al., 1978; and Thomas and Adams, 1978). Several intrinsic and extrinsic factors influence the concentrations, including age (Irvine and Evans, 1975), season (Katovich et al., 1974), stage of training (Takagi et al., 1974) and pregnancy (De Martin, 1977). Using of medicines also had an effect for example phenylbutazone has been shown to decrease thyroid hormone concentrations (Morris and Garcia, 1983, Sojka et al., 1993).

The aim of this study was to investigate the possible toxic effects, if any, of administration of Doramectin Injectable formulation for seven continuous days intramuscularly on $\mathrm{T}_{3}, \mathrm{~T}_{4}$ and TSH hormones.

\section{MATERIALS and METHODS}

Design of the experiment: Four groups of animals were used in this study. Each group comprised of five animals (three male and two female donkeys). They were 4-10 years old. The animals in the treatment groups (DRMTOX1, DRMTOX2 and DRMTOX3) received a daily 
intramuscular injection of Doramectin (Dectomax injection 1.0\% w/v sterile solution of Doramectin, Pfizer. France) for a whole week, at three different dose levels viz: 100, 200 and $300 \mu \mathrm{g} / \mathrm{kg}$ body weight, respectively. The fourth group remained untreated as control group. Then blood samples were collected for hormonal assays, after each injection animals were monitored for two hours for any untoward effects.

Collection of blood: Blood samples were collected before the administration of the drug (day zero) and then daily for the first week after the administration of the drug and then every week for three additional weeks. Whenever blood samples were taken they were allowed to clot, the clotted blood samples were centrifuged and sera were separated and stored at $-20{ }^{\circ} \mathrm{C}$ until analyzed.

Hormones detection: Thyroxine $\left(\mathrm{T}_{4}\right)$ and triiodothyronine $\left(\mathrm{T}_{3}\right)$ were measured in donkey's serum using RIA Kit (Beijing Atom High-tech. Co. LTD). Whereas thyroid stimulating hormone (TSH) was measured using the IRMA technique. The principal method of this immunoradiometeric assay (IRMA) kit utilizes two site sandwich immuno-radiometric assay for the measurement of TSH in serum. This involves the reaction of TSH present in serum with monoclonal and polyclonal antibody. The monoclonal antibody is labeled with $\mathrm{I}^{125}$ as tracer $\left(\mathrm{I}^{125}-\mathrm{McAb}\right)$ and the polyclonal antibody is coupled to magnetic iron oxide particle $(\operatorname{PcAb}\{\mathrm{M}\})$. The formed complex was separated using a magnetic separator.

The values were expressed in $\mathrm{ng} / \mathrm{ml}$ for $\mathrm{T}_{3}$ and $\mathrm{T}_{4}$ whereas for TSH in mIU/L. However, both methods used (RIA and IRMA) are able to detect the thyroid hormones with sensitivity of $0.08 \mathrm{ng} / \mathrm{ml}$, $0.13 \mathrm{ng} / \mathrm{ml}$, and $0.24 \mathrm{mIU} / \mathrm{L}$ for $\mathrm{T}_{3}, \mathrm{~T}_{4}$ and $\mathrm{TSH}$ respectively.

Statistical methods: SPSS 11.5 for Windows computer package was utilized in assessing significant differences, if any. Analysis of variance (ANOVA) was used to compare between means.

\section{RESULTS}


Table 1: Changes in triiodothyronine $\left(\mathrm{T}_{3}\right)$ level $(\mathrm{ng} / \mathrm{ml})$ following administration of doramectin at three different dose rate.

\begin{tabular}{|c|c|c|c|c|}
\hline \multirow{2}{*}{ Days } & Control & DRMT1 & DRMT2 & DRMT3 \\
\cline { 2 - 5 } & Mean \pm SD & Mean \pm SD & Mean \pm SD & Mean \pm SD \\
\hline 0 & $0.88 \pm 0.40^{*}$ & $0.79 \pm 0.24^{*}$ & $1.21 \pm 0.37^{*}$ & $0.85 \pm 0.17^{*}$ \\
\hline 1 & $1.00 \pm 0.33$ & $1.01 \pm 0.80$ & $1.84 \pm 0.53$ & $1.37 \pm 0.87$ \\
\hline 2 & $0.88 \pm 0.55$ & $0.87 \pm 0.44$ & $1.03 \pm 0.47$ & $0.74 \pm 0.48$ \\
\hline 3 & $0.77 \pm 0.37$ & $0.92 \pm 0.40$ & $1.21 \pm 0.22$ & $0.86 \pm 0.27$ \\
\hline 4 & $1.16 \pm 0.31$ & $1.00 \pm 0.70$ & $0.74 \pm 0.25$ & $0.72 \pm 0.61$ \\
\hline 5 & $2.25 \pm 0.49 *$ & $1.96 \pm 0.36^{*}$ & $2.21 \pm 0.42^{*}$ & $2.31 \pm 1.01 *$ \\
\hline 6 & $2.01 \pm 0.25^{*}$ & $2.12 \pm 0.11^{*}$ & $1.82 \pm 0.24$ & $2.27 \pm 0.99 *$ \\
\hline 7 & $1.94 \pm 0.48^{*}$ & $1.64 \pm 0.34^{*}$ & $1.70 \pm 0.24$ & $1.86 \pm 0.41 *$ \\
\hline 14 & $2.13 \pm 0.93 *$ & $2.23 \pm 0.41^{*}$ & $2.77 \pm 1.12^{*}$ & $2.23 \pm 0.35^{*}$ \\
\hline 21 & $2.38 \pm 0.76^{*}$ & $1.88 \pm 0.79^{*}$ & $2.55 \pm 0.57^{*}$ & $2.04 \pm 0.50^{*}$ \\
\hline 28 & $2.57 \pm 0.97 *$ & $1.70 \pm 0.43^{*}$ & $1.87 \pm 0.34$ & $2.03 \pm 0.45^{*}$ \\
\hline
\end{tabular}

*Significant difference $(\mathrm{P}<0.05)$ in comparison with day zero.

Table 2: Changes in thyroxine $\left(\mathrm{T}_{4}\right)$ level $(\mathrm{ng} / \mathrm{ml})$ following administration of doramectin at three different dose rate.

\begin{tabular}{|c|c|c|c|c|}
\hline \multirow{2}{*}{ Days } & Control & DRMT1 & DRMT2 & DRMT3 \\
\cline { 2 - 5 } & Mean \pm SD & Mean \pm SD & Mean \pm SD & Mean \pm SD \\
\hline 0 & $10.47 \pm 8.56^{*}$ & $10.23 \pm 5.49^{*}$ & $12.12 \pm 7.42^{*}$ & $11.72 \pm 3.41^{*}$ \\
\hline 1 & $14.60 \pm 10.86$ & $7.86 \pm 6.17$ & $13.16 \pm 9.48$ & $9.66 \pm 11.81$ \\
\hline 2 & $4.21 \pm 4.40$ & $5.81 \pm 3.89$ & $10.00 \pm 5.28$ & $7.01 \pm 4.34$ \\
\hline 3 & $8.35 \pm 7.48$ & $5.42 \pm 2.68$ & $6.54 \pm 1.14$ & $3.60 \pm 2.74$ \\
\hline 4 & $11.61 \pm 7.14$ & $4.93 \pm 1.25$ & $11.08 \pm 8.67$ & $7.58 \pm 3.77$ \\
\hline 5 & $28.94 \pm 5.87^{*}$ & $36.53 \pm 15.88^{*}$ & $30.11 \pm 10.08$ & $31.03 \pm 13.91^{*}$ \\
\hline 6 & $26.55 \pm 15.74^{*}$ & $21.55 \pm 5.64^{*}$ & $36.39 \pm 12.85^{*}$ & $23.21 \pm 5.26^{*}$ \\
\hline 7 & $18.46 \pm 6.87$ & $21.76 \pm 5.33^{*}$ & $54.06 \pm 34.48^{*}$ & $30.73 \pm 12.38^{*}$ \\
\hline 14 & $16.47 \pm 9.07$ & $17.44 \pm 4.38$ & $14.70 \pm 5.29$ & $14.98 \pm 4.02$ \\
\hline 21 & $19.46 \pm 3.64$ & $21.98 \pm 9.26^{*}$ & $24.10 \pm 9.50$ & $22.33 \pm 7.70$ \\
\hline 28 & $32.86 \pm 19.13 *$ & $24.40 \pm 7.69^{*}$ & $24.39 \pm 13.29$ & $35.49 \pm 4.70^{*}$ \\
\hline
\end{tabular}

* Significant difference $(\mathrm{P}<0.05)$ in comparison with day zero. 
Table 3: Changes in thyroid stimulating hormone (TSH) level (mIU/L) following administration of doramectin at three different dose rate.

\begin{tabular}{|c|c|c|c|c|}
\hline \multirow{2}{*}{ Days } & Control & DRMT1 & DRMT2 & DRMT3 \\
\cline { 2 - 5 } & Mean \pm SD & Mean \pm SD & Mean \pm SD & Mean \pm SD \\
\hline 0 & $0.70 \pm 0.30$ & $0.55 \pm 0.40$ & $0.59 \pm 0.47$ & $0.58 \pm 0.41$ \\
\hline 1 & $0.72 \pm 0.53$ & $0.93 \pm 0.53$ & $0.77 \pm 0.14$ & $0.72 \pm 0.15$ \\
\hline 2 & $0.71 \pm 0.49$ & $0.64 \pm 0.49$ & $0.90 \pm 0.21$ & $0.47 \pm 0.50$ \\
\hline 3 & $0.95 \pm 0.15$ & $0.55 \pm 0.42$ & $1.05 \pm 0.34$ & $0.55 \pm 0.37$ \\
\hline 4 & $0.89 \pm 0.33$ & $0.57 \pm 0.25$ & $0.58 \pm 0.50$ & $0.68 \pm 0.07$ \\
\hline 5 & $1.05 \pm 0.24$ & $0.39 \pm 0.28$ & $0.78 \pm 0.55$ & $0.48 \pm 0.37$ \\
\hline 6 & $0.89 \pm 0.79$ & $0.75 \pm 0.34$ & $0.97 \pm 0.29$ & $0.69 \pm 0.19$ \\
\hline 7 & $0.57 \pm 0.46$ & $0.74 \pm 0.55$ & $0.96 \pm 0.19$ & $0.67 \pm 0.51$ \\
\hline 14 & $0.87 \pm 0.13$ & $0.87 \pm 0.36$ & $1.03 \pm 0.12$ & $0.72 \pm 0.57$ \\
\hline 21 & $1.24 \pm 0.44$ & $1.01 \pm 0.10$ & $0.91 \pm 0.46$ & $0.87 \pm 0.27$ \\
\hline 28 & $0.93 \pm 0.22$ & $1.36 \pm 0.79$ & $0.93 \pm 0.55$ & $1.07 \pm 0.52$ \\
\hline
\end{tabular}

* Significant difference $(\mathrm{P}<0.05)$ in comparison with day zero.

\section{DISCUSSION}

In this study the effect of Doramectin injection on $\mathrm{T}_{3}, \mathrm{~T}_{4}$ and TSH profile was investigated, as shown in Table (1). There is no significant $(\mathrm{P}>0.05)$ difference in triiodothyronine $\left(\mathrm{T}_{3}\right)$ level between the treatment groups and the control group. The level of $\mathrm{T}_{3}$ showed simultaneous increase in the control and treated groups when compared with pretreatment level from day 5 post treatment to the end of the experiment as shown in Table (1).

From Table (2), it is to be seen that thyroxine level $\left(\mathrm{T}_{4}\right)$ did not show any significant differences between the treatment groups and the control. The level of the hormone showed simultaneous increase in all groups from day 5 post treatment and onwards when compared with the pretreatment level as shown in Table (2).

From Table (3), we could observe that thyroid stimulating hormone (TSH) level did not show any significant difference between the treatment groups, and when compared with the pretreatment level within the treatment groups as shown in Table (3).

The avermectins mechanism of toxicity in mammals is unknown but gamma amino butyric acid (GABA) is a mammalian nervous system neurotransmitter and effect on GABA may be relevant to their safety in 
mammals (Lankas and Gordon, 1989). In contrast to lower organisms, GABA is found only in the brain and spinal cord of mammals, with no detectable levels in the peripheral nervous system (Cooper, 1982). However, its concentration varies in different regions, with the greatest concentrations found in the basal ganglia, hippocampus, cerebellum, and hypothalamus in the brain and in the substantia gelatinosa of the dorsal horn of the spinal cord (Steffey, 2001).

In this study the effect of treatment on thyroid hormones revealed non significant difference $(\mathrm{P}>0.05)$ between the treatment groups and the control which indicates that Doramectin Injectable at these dose levels did not have any effect on thyroid hormones. The increase in thyroid hormones concentration in the treated groups occurred at the same time in the control animals.

\section{CONCLUSION}

We conclude that Doramectin Injectable formulation at the dose regimen used here had no effect on thyroid stimulating hormone and thyroid hormones.

\section{ACKNOWLEDGMENTS}

The generous financial support granted by the Central Veterinary Research Laboratory (CVRL) Soba, National Centre for Research (NCR), Sudan and German Academic Exchange Service (DAAD) was greatly acknowledged. Due thanks are also extended to the staff members of the Department of Radioisotopes (CVRL).

\section{REFERENCES}

Cooper, J.R. (1982): Amino acids. In: The Biochemical Basis of Neuropharmacology, $4^{\text {th }}$ Ed., (Cooper J.R., Bloom F.R., Roth R.H. Eds.). Oxford University Press. Pp. 250.

De Martin, D.W. (1977): Study on the thyroid function of male and female Thoroughbred horses in different times after winning races at the Hippodrome Cidade Jardin, with the use of "in vitro" ${ }^{125} \mathrm{I}-\mathrm{T}_{3}$ and ${ }^{125} \mathrm{I}-\mathrm{T}_{3}$ tests. Rev. Fac. Med. Vet. Zootec. Univ. S. Paulo. 14, 199-203.

Goudie, A.C.; Evans, N.A.; Gration, K.A.; Bishop, B.F.; Gibson, S.P. Holdmom, K.S.; Kaye, B.; Wicks, S.R.; Lewis, D.A.; Weatherley, J.; Bruce, C.; Herbert, A. and Seymour, D. (1993): Doramectin - a potent novel endectocide. Vet. Parasitol. 49(1): 5-15. 
Irvine, C.H.G. and Evans, M.J. (1975): Post - natal changes in total and free thyroxine and triiodothyronine in foal serum. J. Reprod. Fertil. (suppl), 23: 709-715.

Kallfelz, F.A. and Eralli, R.P. (1973): Thyroid function tests in domesticated animals: free thyroxine index. Am. J. Vet. Res. 34: 1449-1451.

Katovich, M.; Evans, J.W. and Sanchez, O. (1974): Effects of season, pregnancy and lactation on thyroxine turnover in the mare. J. Anim. Sci. 38: 811-818.

Lankas, G.R. and Gordon, L.R. (1989): Toxicology. In Ivermectin and Abmectin. Edited by W.C. Campbell. Springer Verlag. New York Inc. p. 89-112. $1^{\text {st }}$ ed.

Morris, D.D. and Garcia, M. (1983): Thyroid-stimulating hormone: response test in healthy horses, and effect of phenylbutazone on equine thyroid hormones. Am. J. Vet. Res. 44, 503-507.

Reap, M.; Cass, C. and Hightower, D. (1978): Thyroxine and triiodothyronine levels in ten species of animals. Southwest Vet. 31, 31-34.

Sojka, J.E.; Johnson, M.A. and Bottoms, G.D. (1993): Serum triiodothyronine, total thyroxine, and free thyroxine concentrations in horses. Am. J. Vet. Res. 54 (1): 52-55.

Steffey, E.P. (2001): Introduction to drugs acting on the central nervous system and principles of anesthesiology. In: Veterinary Pharmacology and Therapeutics (H. Richard Adams, Edi.). Iowa State Press. 2121 State Avenue, Ames, Iowa. pp. 158.

Takagi, S.; Ito, K. and Shibata, H. (1974): Effects of training on plasma fibrinogen concentration and thyroid hormone level in young race horses. Exp. Rep. Equine Hlth. Lab. 11, 94-105.

Thomas, C.L. Jr., and Adams, J.C. (1978): Radioimmunoassay of equine serum for thyroxine: reference values. Am. J. Vet. Res.; 39 (7): 1239 . 